\title{
Physiological role of Prion Protein in Copper homeostasis and angiogenic mechanisms of endothelial cells
}

\author{
Lidia De Riccardis $^{1 ¥}$, Francesca Rizzo $^{1 \neq}$, Emanuela Urso $^{1}$, Valeria Garzarelli ${ }^{1}$, Vincenza Intini ${ }^{1}$, \\ Marco Greco ${ }^{1}$, Maria Chiara Maffia ${ }^{2}$, Antonio Danieli ${ }^{1}$ and Michele Maffia ${ }^{1,3 *}$
}

\begin{abstract}
The Prion Protein (PrP) is mostly known for its role in prion diseases, where its misfolding and aggregation can cause fatal neurodegenerative conditions such as the bovine spongiform encephalopathy and human Creutzfeldt-Jakob disease. Physiologically, PrP is involved in several processes including adhesion, proliferation, differentiation and angiogenesis, but the molecular mechanisms behind its role remain unclear. PrP, due to its well-described structure, is known to be able to regulate copper homeostasis; however, copper dyshomeostasis can lead to developmental defects. We investigated PrP-dependent regulation of copper homeostasis in human endothelial cells (HUVEC) using an RNA-interference protocol. PrP knockdown did not influence cell viability in silenced HUVEC (PrPKD) compared to control cells, but significantly increased PrPKD HUVEC cells sensitivity to cytotoxic copper concentrations. A reduction of PrPKD cells reductase activity and copper ions transport capacity was observed. Furthermore, PrPKD-derived spheroids exhibited altered morphogenesis and their derived cells showed a decreased vitality 24 and 48 hours after seeding. PrPKD spheroid-derived cells also showed disrupted tubulogenesis in terms of decreased coverage area, tubule length and total nodes number on matrigel, preserving unaltered VEGF receptors expression levels. Our results highlight PrP physiological role in cellular copper homeostasis and in the angiogenesis of endothelial cells.
\end{abstract}

Keywords: Prion Protein, copper transport, HUVEC cells, angiogenesis, siRNA

'Dept. of Biological and Environmental Science and Technology, University of Salento, Lecce, Italy

${ }^{2}$ San Raffaele -Telethon Institute for Gene Therapy, Vita Salute San Raffaele University, Milan, Italy

"Lab of Clinical Proteomic, "V. Fazzi" Hospital, Lecce, Italy

$¥$ These authors have contributed equally to the work

${ }^{*}$ Corresponding author: M. Maffia E-mail: michele.maffia@unisalento.it

DOI: 10.2478/ebtj-2019-0007 (c) 2019 Authors. This work was licensed under the Creative Commons AttributionNonCommercial-NoDerivs 4.0 License.

\section{Introduction}

The prion protein $(\mathrm{PrP})$ is known for its involvement in regenerative processes including adhesion, proliferation, differentiation and angiogenesis (1); in addition, it is mostly known for its role in prion diseases, where its misfolding and aggregation can cause fatal neurodegenerative conditions such as the bovine spongiform encephalopathy, scrapie of sheep and human Creutzfeldt - Jakob disease (2).

The protein contains several high affinity binding sites for copper ions (3) and its structure evolved from a common ZIP (Zrt-and Irt - like protein) ancestor gene (4). PrP structure consists of a C-terminal globular domain and an $\mathrm{N}$-terminal flexible tail, containing two charged clusters (CC1 and CC2), the octarepeat region (OR) and a hydrophobic domain (HD) (5). At the C-terminus, two N-glycosylation sites are located in the globular domain (6-8). PrP is located extracellularly in the lipid rafts, anchored to the outer lipidic monolayer by the glycosyl-phosphatidylinositol (GPI) anchor (5). Thanks to a rapid constitutive clathrin-/cavolein-dependent process (9-11), PrP is endocyted and then recycled or degraded $(12,13)$. The protein can also regulate intracellular copper content through its ability to bind the metal ions and promote their endocytosis (14-17). In fact, the histidine residues present at the PrP N-terminal domain can bind up to 6 copper ions with low affinity (18-20) triggering their cellular internalization at the synaptic cleft $(9,12,21,22)$. However, PrP role in copper uptake is still debated due to contrasting data (23). 
Copper plays an essential role in many biological processes, also due to its redox ability of changing between oxidized $\left(\mathrm{Cu}^{2+}\right)$ and reduced state $\left(\mathrm{Cu}^{+}\right)$. Under physiological condition, copper concentration is strictly regulated; copper deficiency or genetic mutation of metal ions transporters could lead to developmental defects $(24,25)$; on the other hand, its excess would increase free radicals toxic concentrations and cause oxidative damage within the cell $(24,26)$.

The expression of PrP in microvascular brain endothelial cells has been demonstrated by several authors $(27,28)$, also within the human placenta, suggesting the importance of this protein in the angiogenetic process and in regulating copper metabolism during the development of the foeto-maternal circulatory system (29). The hypoxic microenvironment of early gestation (29) may stimulate PrP expression through HIF-1a, as its silencing down-regulates PrP expression under hypoxia (30-32), by means of an SP1 (specific protein 1) transcription factor-dependent mechanism (33-37). Recent evidence links vascular dysfunctions and neurodegenerative conditions demonstrating how an altered copper supply can be a triggering factor $(38,39)$ and supporting the AD "two-hit vascular hypothesis", where a cerebrovascular damage (hit 1 ) is self-sufficient to initiate neuronal injury and neurodegeneration (40-43).

In this work we were able to demonstrate, for the first time, the functional expression of PrP in HUVEC (human umbelical vein endothelial cells). Therefore, we investigated the physiological role of PrP and copper ions in the angiogenetic processes by using an in vitro model of HUVEC knocked down for this protein. Our results show that $\operatorname{PrP}$ is involved in copper reduction and in its cellular uptake through an endocytic process; furthermore, PrP knockdown is able to modify the cell morphology and the tubulogenesis capacity in matrigel, thus demonstrating a morphogenetic and angiogenic potential of this protein.

\section{Material and Methods \\ HUVEC cell line}

The endothelial cell model used in the present study is represented by the HUVEC (Human Umbilical Vein Endothelial Cells) primary cell line. Cells were isolated by digestion of endothelial fractions derived from the umbilical cord vein collecting in the Gynecology and Obstetrics unit of the "Vito Fazzi" hospital in Lecce, within 24 hours from their withdrawal. Informed consent was obtained from each subject, according to the declaration of Helsinki. The umbilical cords have been preliminarily treated with a disinfectant solution, then washed with PBS (Sigma-Aldrich, Milan) containing antibiotics (Penicillin/Streptomycin; Sigma-Aldrich) and an antimycotic (Amphotericin B) and then perfused by cannulation to remove blood residues. Collagenase IV solution $(0.1 \%$ in PBS, Sigma-Aldrich) was then injected into the vein. Umbilical cords were transferred to the incubator $\left(37^{\circ} \mathrm{C}\right)$ for 20 minutes, in order to allow the enzymatic digestion. The endothelial fraction was collected in a Falcon tube containing bovine fetal serum (FBS; Sigma- Aldrich) and cell suspension was centrifuged for
8 minutes at $1000 \mathrm{~g}$. The pellet was washed twice in PBS and cells were resuspended in fresh culture medium (M199 Euroclone, Life Science Division) and seeded in pre-treated $0.2 \%$ gelatin/PBS T25 flasks. For experimental tests, endothelial cells were used within two and four passages.

\section{MTT test}

Cells were plated into 96-well trays and $0.5 \mathrm{mg} / \mathrm{ml} \mathrm{MTT}$ [3-(4,5-dimethylthiazol-2-yl)-2,5-diphenyl-tetrazolium bromide; Sigma-Aldrich] was added to cell cultures for $3 \mathrm{~h}$ at $37^{\circ} \mathrm{C}$. The MTT formazan product was released from cells by adding dimethylsulfoxide and measured spectrophotometrically at $570 \mathrm{~nm}$ (44). The percent of survival was assessed by comparison with untreated cultures. The estimation of viable cells is expressed as a percentage of the optical density values acquired compared to the controls.

\section{Real-Time PCR}

RNA extraction from cells grown at $70-80 \%$ confluence was performed by using the TRIzol reagent (Invitrogen, Milan, Italy), accordingly to the manufacturer's instructions. Total RNA $(0.5 \mu \mathrm{g})$ was reverse-transcribed with random hexamers in a $20 \mu \mathrm{l}$ reaction volume by the GeneAmp Gold RNA PCR kit (Perkin-Elmer, Monza, Italy). Amounts of cDNA template from 0.2 to $0.5 \mu \mathrm{g}$ were needed for real-time PCR analysis. Primers and annealing sequences are listed in Table 1. Reactions were carried out into a $25-\mu \mathrm{l}$ mixture volume using the SmartCycler System (Cepheid, Euroclone, Milan, Italy) and the threshold cycles $(\mathrm{Ct})$ were averaged from three samples, each analysed in duplicate. The average expression ratio of genes with respect to the control condition was computed by Pfaffl's formula (45).

\section{Western blotting}

The cell lysis protocol was applied to semi-confluent monolayers, performing all operations on ice. Preliminarily two washes with PBS were carried out, after which the cell lysis was performed in RIPA buffer (Tris- $\mathrm{HCl} 50 \mathrm{mM}, \mathrm{pH}$ 7.4, NP$401 \%$, Sodium-deoxycholate $0.25 \%, \mathrm{NaCl} 150 \mathrm{mM}$, EDTA 1 $\mathrm{mM}$, PMSF $1 \mathrm{mM}, \mathrm{Na}_{3} \mathrm{VO}_{4} 1 \mathrm{mM} ; 0.5 \mathrm{ml}$ for $10^{6}$ cells). Protein extracts $(\sim 30 \mu \mathrm{g})$ were boiled in Laemmli sample buffer (Sigma-Aldrich) for $5 \mathrm{~min}$, resolved on $10 \%$ SDS-polyacrylamide gels and transferred onto nitrocellulose membranes at $190 \mathrm{~mA}$ for $1.5 \mathrm{~h}$. Membranes were blocked for $1 \mathrm{~h}$ in Tris-buffered saline (TBS), 0.05\% Tween-20, 5\% non-fat dry milk, followed by overnight incubation with specific primary antibodies diluted in the same buffer. The primary antibodies used are: anti-PrP (1:8000, Sigma-Aldrich) and anti- $\beta$-actin (1:8000, Sigma-Aldrich). After washing with $0.1 \%$ Tween in TBS, membranes were incubated with a peroxidase-conjugated secondary antibody for $1 \mathrm{~h}$, washed and developed using the ECL chemiluminescent detection system (Clarity ${ }^{\text {Tm }}$ Western ECL Substrate Biorad). The densitometric analyses of blots were performed by a computerized image processing system (Image J, 1.0 version). 
Table 1. Real-time PCR primer sequences and conditions

\begin{tabular}{|c|c|c|c|c|}
\hline Target gene (host) & $\begin{array}{c}\text { GenBank accession } \\
\text { no. }\end{array}$ & Primers (sense, antisense) & $\mathrm{T}_{\mathrm{m}}\left({ }^{\circ} \mathrm{C}\right)$ & bp \\
\hline $\begin{array}{l}\text { GADPH ( } R \text {. norvegi- } \\
\text { cus) }\end{array}$ & NM_017008 & $\begin{array}{l}\text { Fw 5'-CTGCTCCTCCCTGTTCTAGAGACA-3' } \\
\text { Rv 5'-CCGATACGGCCAAATCCGTTCACA-3' }\end{array}$ & 58 & 105 \\
\hline PrPC (H. sapiens) & NM_000311.3 & $\begin{array}{l}\text { Fw 5'-AACCTCAAGCATGTGGCAGG-3' } \\
\text { Rv 5'-CTCCCAGTCGTTGCCAAAAT -3' }\end{array}$ & 56 & 117 \\
\hline KDR (H. sapiens) & NM_002253 & $\begin{array}{l}\text { Fw 5'- TGCCTACCTCACCTGTTTC -3' } \\
\text { Rv 5'- GGCTCTTTCGCTTACTGTTC -3' }\end{array}$ & 62 & 114 \\
\hline Flt-1 (H. sapiens) & NM_002019 & $\begin{array}{l}\text { Fw 5'-CGTAGAGATGTACAGTGAAA-3' } \\
\text { Rv 5'-GGTGTGCTTATTTGGACATC-3' }\end{array}$ & 58 & 306 \\
\hline
\end{tabular}

\section{RNA interference (RNAi) protocol}

PrP-targeting siRNAs have been provided from Ambion (Life Technologies Italia, Monza, MB) in the Silencer ${ }^{\circledast}$ Select Pre-Designed \& Validated formulation. In particular, we used two different siRNAs (ID s11212, s11213) for the target gene (PRNP), one scrambled siRNA as negative control and the transfectant agent siPORT NeoFXTM (Ambion), preliminarily diluted in

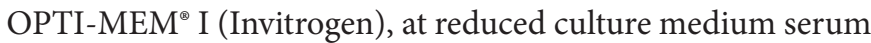
content, in order to vehicle them into the cell.

The gene silencing experiments were set up in 12-well plates and each of the experimental conditions listed as follow were tested in duplicate: control (incubation with the transfectant agent in the absence of siRNA), negative control (transfection with $30 \mathrm{nM}$ scrambled siRNA), transfection with siRNA ID $1121230 \mathrm{nM}$, transfection with siRNA ID $1121330 \mathrm{nM}$, simultaneous transfection with the two siRNAs, both tested at concentration of $15 \mathrm{nM}$. After a short incubation period, the siRNA/siPORT NeoFX complexes transfection agents were distributed in the multi-well plate $(100 \mu \mathrm{L} /$ well $)$ immediately before cell seeding. The expression levels of the prion protein were analyzed by Western Blotting after $48 \mathrm{~h}$ from transfection.

\section{Membrane $\mathrm{Cu}^{2+}$-reductase activity assay}

Confluent HUVEC cell cultures seeded in a 12-well plate have been used for membrane $\mathrm{Cu}^{2+}$-reductase activity assay. Monolayer cells have been washed with PBS and incubated for 3-15 $\mathrm{min}$ at $37^{\circ} \mathrm{C}$, with HBSS buffer containing $\mathrm{Cu}-\mathrm{His}_{2}$ (10-50 $\mu \mathrm{M})$ and the copper ions chelation agent bathocuproine-disulfonic acid disodium salt (BCS; Sigma-Aldrich, Milano) $200 \mu \mathrm{M}$. The BCS- $\mathrm{Cu}^{+}$complex formation (molar extinction coefficient $\varepsilon=12.25 \mathrm{mM}^{-1} \mathrm{~cm}^{-1}$ ) within the cell culture medium has been assessed by spectrophotometer reading at $\lambda=482 \mathrm{~nm}$. Data have been normalized on the cell lysate protein content of each well.

\section{Cellular $\mathrm{Cu}^{2+}$-uptake}

The kinetics of $\mathrm{Cu}$ intake were studied in HUVEC control and PrPKD cells using the green-fluorescent heavy metal indicator Phen Green SK diacetate (PG SK) $\lambda_{\text {exc }}=506 \mathrm{~nm}, \lambda_{\mathrm{em}}=530 \mathrm{~nm}$; Molecular Probes, Invitrogen). Cells were harvested and then dye-loaded by incubation for $10 \mathrm{~min}$ at $37^{\circ} \mathrm{C}$ in HBSS (in $\mathrm{mM}$ : $140 \mathrm{NaCl}, 5 \mathrm{KCl}, 1 \mathrm{Na}_{2} \mathrm{HPO}_{4}, 1 \mathrm{CaCl}_{2}, 0.5 \mathrm{MgCl} 2,5 \mathrm{D}$-glucose, 10 Hepes; pH 7.4) containing $1 \mu \mathrm{M}$ PG SK. After loading, cells were washed twice by centrifugation and then resuspended in the physiological buffer cited above. For each evaluation, an aliquot of cells $\left(3 \times 10^{4}\right)$ was introduced in a cuvette housed in a LS-50B Perkin-Elmer spectrofluorometer, after the preheating of the sample compartment at $37^{\circ} \mathrm{C}$. Once the emission signal of the probe "entrapped" within the cells was stable, $\mathrm{Cu}$ chloride was added at different concentrations $(0-5 \mu \mathrm{M})$ and the fluorescence quenching $\left(\Delta F\right.$ a.u. $\mathrm{s}^{-1} \mathrm{nr}$ cells $\left.\mathrm{s}^{-1} 10^{-5}\right)$ was monitored as an indicator of $\mathrm{Cu}$ influx rates into the cytoplasm. A set of experiments was conducted on both untreated and $\mathrm{Cu}$-depleted cells, before and after the enzymatic removal of surface PrP. In the last case, cultures were washed twice with phosphate-buffered salt solution and then pre-incubated in serum-free medium containing $5 \mathrm{mU} / \mathrm{cm}^{2}$ phosphatidylinositol-specific phospholipase C (PI-PLC) from B. Cereus (Sigma-Aldrich) for 2.5 $\mathrm{h}$ at $37^{\circ} \mathrm{C}$. Cells were dye-loaded as reported above and $\mathrm{Cu}$ transport assays were performed by testing single extracellular $\mathrm{Cu}$ concentrations in separate experiments. The absolute $\mathrm{Cu}$ intake, expressed as a percentage of control, was calculated as $\Delta F_{\max } / F_{0}$ ratio, where $\Delta F_{\max }$ is the maximum quencing in fluorescence observed after the addition of $\mathrm{Cu}$ to cells and $F_{0}$ is the baseline signal.

\section{Spherical cultures}

The HUVEC control and silenced cells (since now on referred to as PrPKD cells) at the same number of passages were trypsinized and resuspended in the M199 culture medium at a density 
of 70.000 cells $/ \mathrm{ml}$. The "hanging drop method" (46) was used to generate the "spheroids pendant". $5 \mathrm{ml}$ of sterile PBS were introduced on the bottom of $60 \mathrm{~mm}$ plates in order to create "wet rooms". Spheroids growth was monitored and images were acquired by an inverted optical microscope in contrast phase mode, at regular intervals of time (0-48 h).

\section{Tubulogenesis test in Matrigel}

$50 \mu \mathrm{L}$ of Matrigel (BD Biosciences) with reduced growth factor content was deposited on the bottom of pre-cooled 96-well plates. In order to allow matrix polymerization, the plates were transferred to $37^{\circ} \mathrm{C}$ for 2 hours. HUVEC control and PrPKD cells were, therefore, seeded at a density of $5000 \mathrm{cells} / \mathrm{cm}^{2}$ and stimulated with VEGF $10 \mathrm{ng} / \mathrm{ml}$ for $16 \mathrm{~h}$. The formation of capillary-like structures was evaluated by observation via an inverted optical microscope in contrast phase mode. The characteristics of the networks (percentage area covered by cells, tubule extension, number of nodes) were analyzed using the WimTube software (Wimasis GmbH, Munich, Germany).

\section{Statistical data processing}

Results are presented as means \pm SE and each experiment has been done at least in triplicate. Statistical comparisons have been made by Student's t test and ANOVA followed by Dunnett's post-test. Significance was demonstrated at $\left.\mathrm{p}<0.05{ }^{*}\right), \mathrm{p}$ $\left.<0.01{ }^{* *}\right)$.

\section{Results}

\section{HUVEC PrP knockdown}

In order to understand the contribution of $\mathrm{PrP}$ in the processes of endothelial activation we used a RNA interference (RNAi) protocol.
The experimental procedure associated with RNAi could cause cellular stress and cytotoxicity, masking the specific effect of the PrP gene down-regulation. In order to critically evaluate this aspect and to avoid the use of toxic amount of transfectant agent, cellular viability assays have been performed. As shown in Figure 1, the administration of scalar quantities of transfectant agent $(0.15-75 \mu \mathrm{l} /$ well $)$ did not cause any significant alterations of cell viability with respect to the control condition ("no siRNA", siPORT NeoFX $0 \mu \mathrm{l} /$ well). Furthermore, the combined use of siRNAs did not produce any significant toxic effect even after $72 \mathrm{~h}$ of incubation time.

After these preliminary assessments, we proceeded to the preparation of the knockdown cultures used for subsequent evaluations. HUVEC cells were transfected with siRNA s11212 and s11213 (used individually or mixed according to the concentrations already mentioned), capable of recognizing different sequences of the PrP transcript. The silencing efficiency rate was checked 2 days after transfection by Real Time PCR analysis (Fig.2a). At any tested experimental condition, the transcript levels were found to be lower than those measured in the control (Fig.2a); in particular, the highest silencing efficiency rate was obtained simultaneously transfecting both siRNAs. In order to quantify the persistence level of the post-transcriptional silencing effect, the values of the transcript expression were measured at $48 \mathrm{~h}$ (Fig. 2c).

In parallel, immunoblotting assay was performed to check the reduction of the PrP protein expression levels (Fig.2b, c).

\section{PrP protects cells from copper-induced cytotoxicity}

The HUVEC control and PrPKD cells were exposed for 24 hours to increasing copper concentrations and cell viability was measured by MTT assay. The cytotoxicity profiles reported in

\section{SiPORT NeoFX $(\mu \mathrm{l})$}
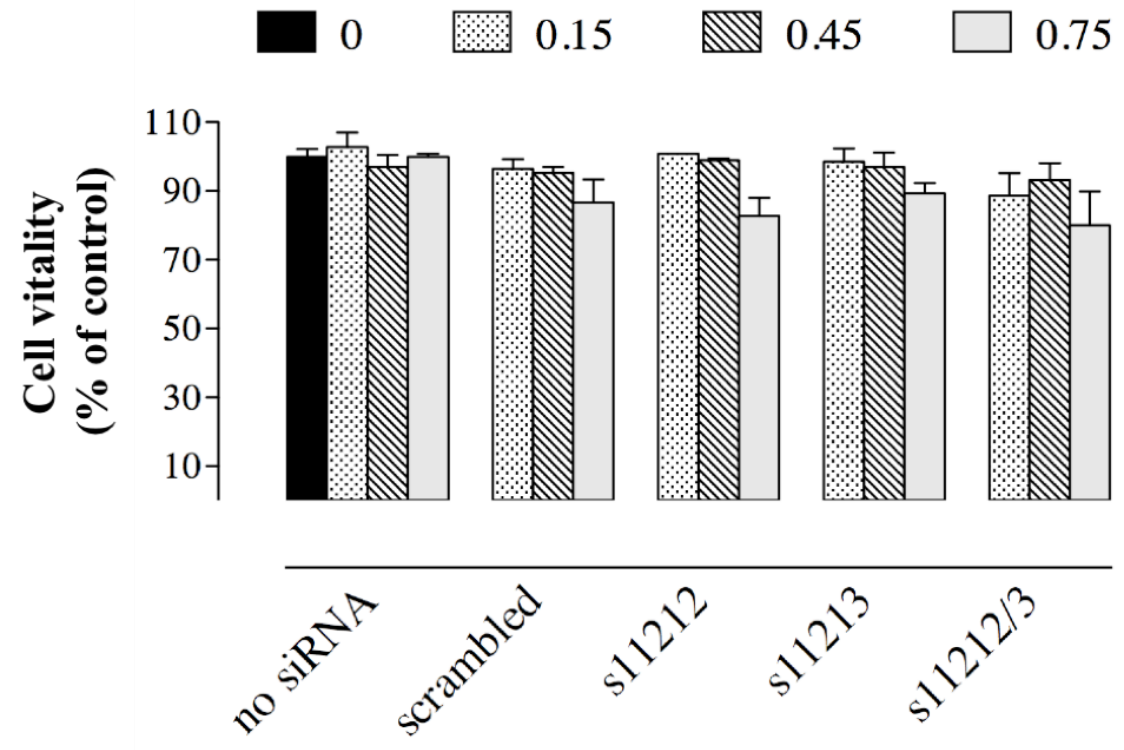

Figure 1. Effect of transfection on cell viability. HUVEC cells seeded in 96 multi-well plates were transfected with the $30 \mathrm{nM}$ siRNA/ siPORT NeoFX complexes, using a variable amount of the lipid agent (0.15-75 $\mu \mathrm{l})$. After $72 \mathrm{~h}$, cell viability was quantified by MTT test; experimental replicates $n=3$. The ANOVA statistical test did not reveal significant differences between the measured average values. 
a)

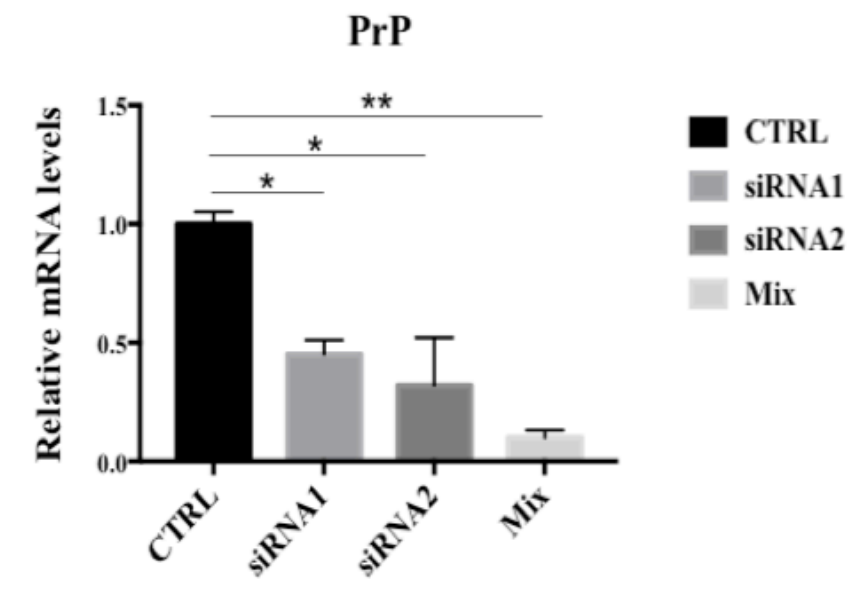

b)

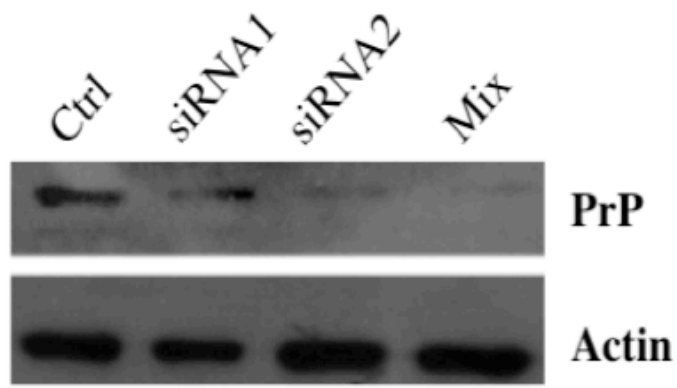

c)

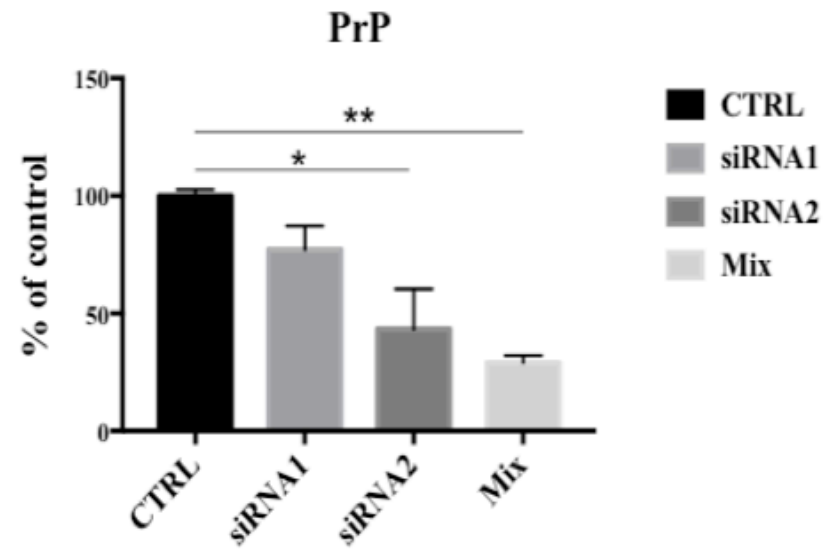

Figure 2. Analysis of the PrP transcript levels. (a) Real Time PCR analysis of the PrP transcript levels was performed in total RNA samples extracted from control (ctrl) e transfected cells at 48h with siRNA s11212 e s11213, administered separately or simultaneously (siRNA mix, control internal: GADPH, experimental replicates $n=3$ ). (b) Western blot analysis of prion protein levels performed on transfected cellular extracts at $48 \mathrm{~h}$ (internal control: $\beta$-actin) (c).

Figure 3 shows how both cultures are sensitive to the dose-dependent effect, with a higher extent for PrPKD cells. In fact, the $\mathrm{EC}_{50}$ values for copper-induced cytotoxicity are $50.78 \pm 1.29$ $\mu \mathrm{M}$ for control cells and $26.06 \pm 1.25 \mu \mathrm{M}$ for PrPKD cells, respectively.

\section{PrP facilitates copper uptake in HUVEC cell line}

According to current hypothesis, copper ions are reduced $\left(\mathrm{Cu}^{+}\right)$before being translocated through the membrane. In the light of in vitro studies showing how PrP N-terminal octarepeat region is able to exert a reductase activity, we decided to test PrP enzymatic function also in the HUVEC cells using a colorimetric assay (Fig.4). HUVEC control and PrPKD cells have been exposed to a high concentration of $\mathrm{Cu}^{2+}(50 \mu \mathrm{M})$ for 15 min together with $\mathrm{Cu}^{+}$chelating BCS.

The absorbance values of the culture medium after incubation showed a marked but still not significant reduction of about 30\% in HUVEC PrPKD with respect to the control cells. As reported in Figure 4 "Cu/BCS", no spontaneous conversion phenomenon of copper ions has been observed. Thus, PrP shows to have a role in copper ions transport facilitating their reduction, a necessary step needed for transmembrane translocation.

PrP usually undergoes recycling between the plasmatic membrane and the endosomal district; so, we decided to investigate any possible association between protein internalization process and copper transport in HUVEC cells. These cells were pre-treated with two different endocytosis inhibitors, Cytochalasin B and Chlorpromazine separately, and exposed for a short time to hypertonic shock in order to evaluate the copper transport activity in different experimental conditions. The cells previously incubated with the Phen Green SK fluorescent dye and were exposed to $\mathrm{Cu}^{2+} 20$ $\mu \mathrm{M}$ (Fig. 5), making it possible to discriminate between the 


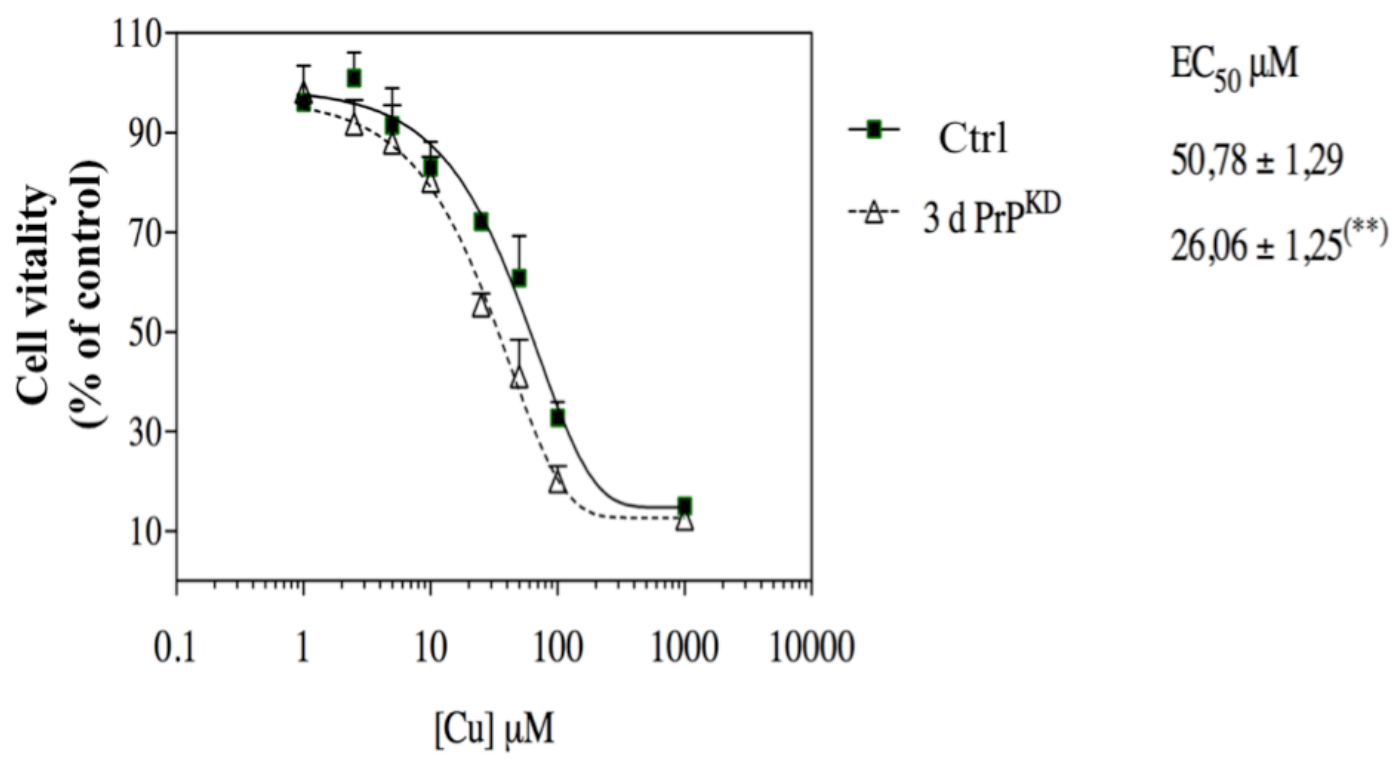

Figure 3. Effect of PrPC protein expression on the copper-induced cytotoxicity profile. Control and PrPKD HUVEC cells were treated for $24 \mathrm{~h}$ with increasing concentrations of copper. The percentage of viable cells, estimated by MTT assay, is compared to the control condition (no treatment). The $\mathrm{EC}_{50}$ (half maximal effective substrate concentration) values belong to each of the dose-response curves and were evaluated using GraphPad Prism 5.0 software; the values in the graph are reported as mean \pm SE and were compared by Student's t test $\left(n=3{ }^{* *} \mathrm{p}<0.01\right)$.

amount of the copper endothelial transport mediated by either dependent or independent endocytosis mechanisms. As shown in Figure 5a, only Cytochalasine B is able to significantly inhibit copper transport. Testing scalar concentrations of Cytochalasin B $(0-100 \mu \mathrm{M})$ we found that the highest dose $(100 \mu \mathrm{M})$ represented the most feasible condition to evaluate the PrP silencing effect on the endocytotic copper transloca- tion (Fig. 5b). The endocytosis inhibitor produced a 50\% reduction of the copper transport in Ctrl cells, while it did not exert any detectable effect on PrPKD cells (Fig. 5c). We can then conclude that copper endocytosis-dependent transport in HUVEC cells is regulated by the prion protein, given also by the high velocity of the experimentally observed copper uptake compatible with a fast-kinetic endocytosis process.

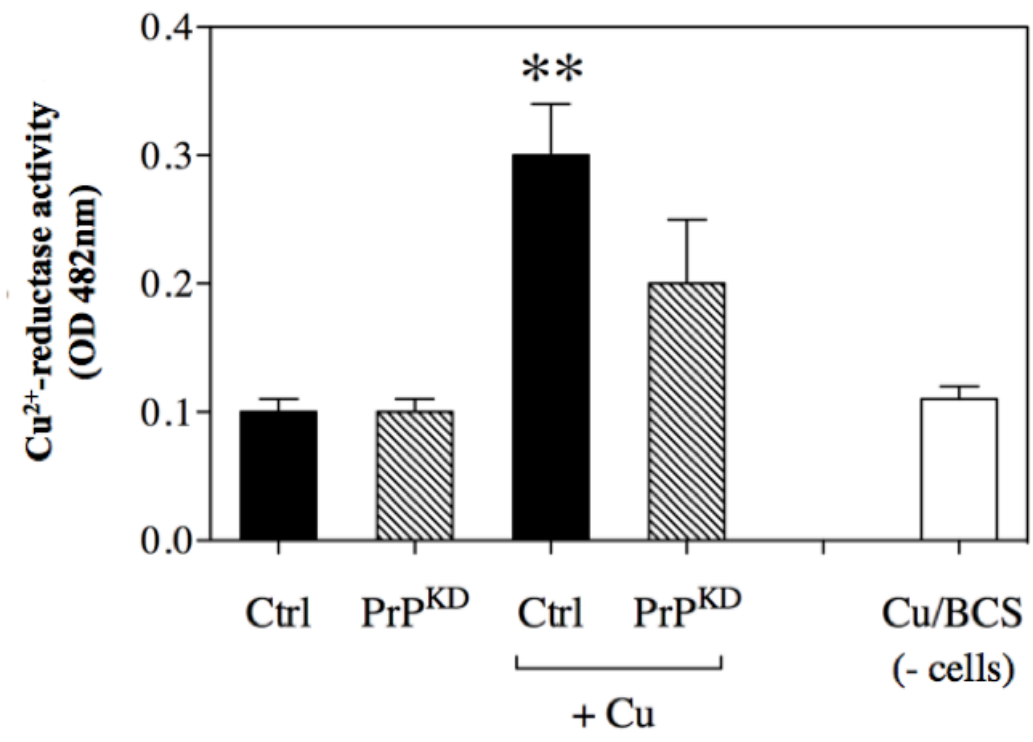

Figure 4. Membrane $\mathrm{Cu}^{2+}$-reductase activity in HUVEC Ctrl and knockdown PrPKD. Copper ions accumulation in culture medium has been evaluated via colorimetric assay of the $\mathrm{Cu} / \mathrm{BCS}$ complex $(482 \mathrm{~nm})$. Data are reported as mean $\pm \mathrm{SE}\left(n=3\right.$; $\left.{ }^{* *} \mathrm{p}<0.01\right)$. 
(a)

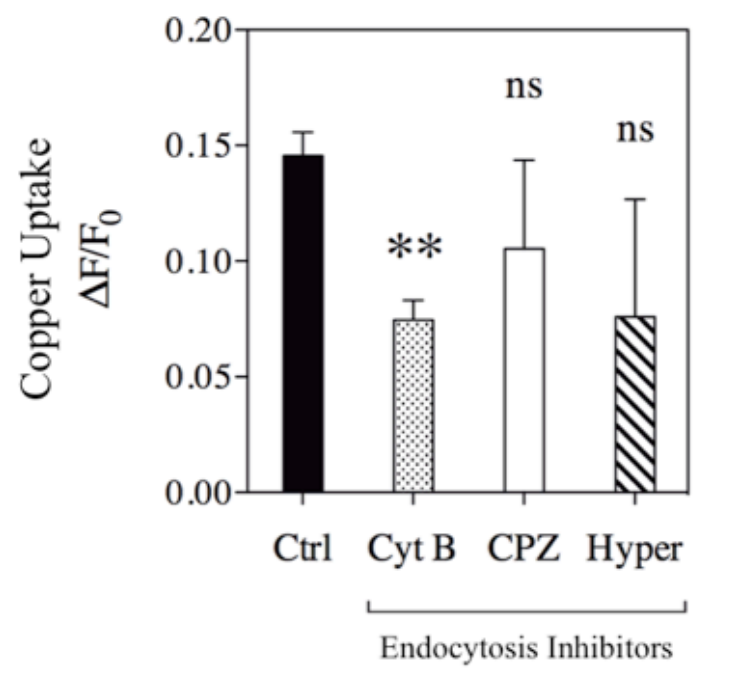

(c)

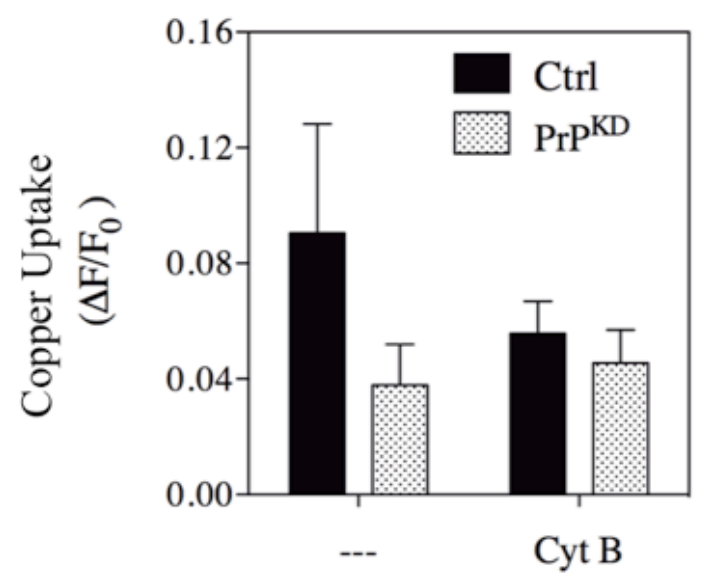

PrP knockdown induced altered HUVEC-derived spheroids morphogenesis

The use of a cell culture protocol in suspension for the generation of spheroids, allowed us to evaluate the ability of PrPKD cells to establish stable interactions with other cellular and extracellular matrix elements. As shown in Figure 6, the morphological analysis of spheroids growth after $16 \mathrm{~h}$ showed an evident irregularity in the aggregates obtained from PrPKD cells. After $48 \mathrm{~h}$, these structures manifested their fragility, showing signs of disaggregation comparable to those of spheroids derived from the control cells. The spheroids are heterogeneous and, because of their architecture, contain a proliferating cell population on their surface and quiescent cells in the centre due to limited access to nutrient and oxygen (47). For this reason, we calculated the percentage of viable cells in control and PrPKD spheroids. These cellular structures underwent mechanical dissociation and the number of released cells was counted. Cell viability levels were significantly lower for PrPKD derived spheroids (Fig. 6). Although this experimental result does not allow to (b)

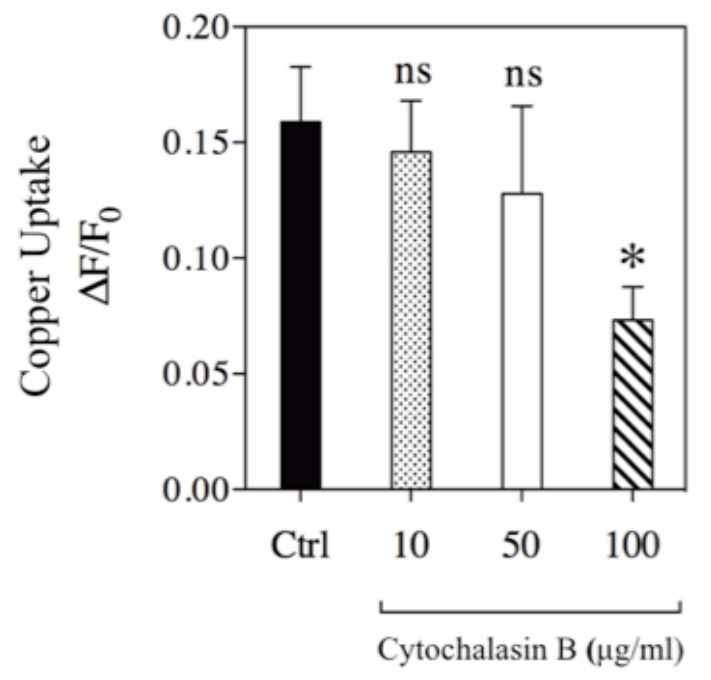

Figure 5. Endocytosis inhibitors effect on the copper accumulation in the HUVEC cells. (a) HUVEC cells have been pre-treated with Cytochalasin B (Cyt B; $100 \mu \mathrm{g} / \mathrm{ml})$, Chlorpromazine (CPZ; $50 \mu \mathrm{M}$ ), or exposed to hypertonic shock (Hyper) for $15 \mathrm{~min}$, before being dyed with Phen Green SK fluorescent indicator and exposed to a Cu-His ${ }_{2}$ concentration of $20 \mu \mathrm{M}$. (b) Cytochalasin B scalar concentrations effect on the ion copper uptake ( $\mathrm{Cu}-\mathrm{His}_{2}$ $20 \mu \mathrm{M} ; \mathrm{n}=3,{ }^{*} \mathrm{p}<0.05$ ). (c) Cytochalasin B effect on the copper uptake in HUVEC Ctrl and PrPKD cells. ( $n=3$; ANOVA, $\left.{ }^{* *} p<0.01\right)$.

discriminate between necrosis and apoptosis phases, it suggests however, a net loss of viability for PrPKD cultures, probably due to a higher sensitivity to a nutrient and/or oxygen deficiency. In details, the values of the cellular vitality are comparable to those observed after $16 \mathrm{~h}$ of cultured cells (Fig. 7). After 24h, a $20 \%$ reduction in PrPKD cultures viability was shown, despite no significant morphological difference emerged between the two conditions. After $48 \mathrm{~h}$, the cell viability reduction reaches approximately $30 \%$ compared to the control (Fig. 7). Indeed, in this phase the PrPKD spheroids resulted fragmented. The presence of blebs around the margin of the PrPKD aggregates as shown in Figure 6 was used as a feature of apoptotic events.

\section{PrP knockdown disrupts HUVEC cells tubulogenesis}

HUVEC control and PrPKD cells were seeded at the same density on a thin layer of Matrigel without growth factors and then stimulated with VEGF $10 \mathrm{ng} / \mathrm{ml}$ for $16 \mathrm{~h}$ to induce the formation of a vascular-like network. Figure 8 shows clearly how PrPKD cells are unable to establish contacts and to shape 

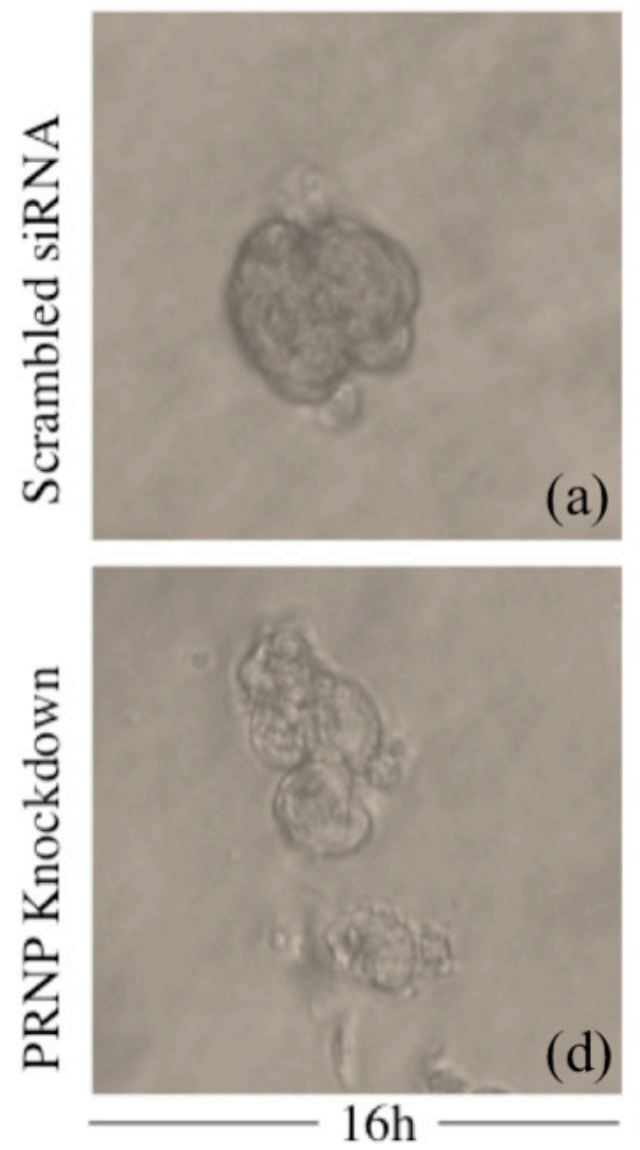
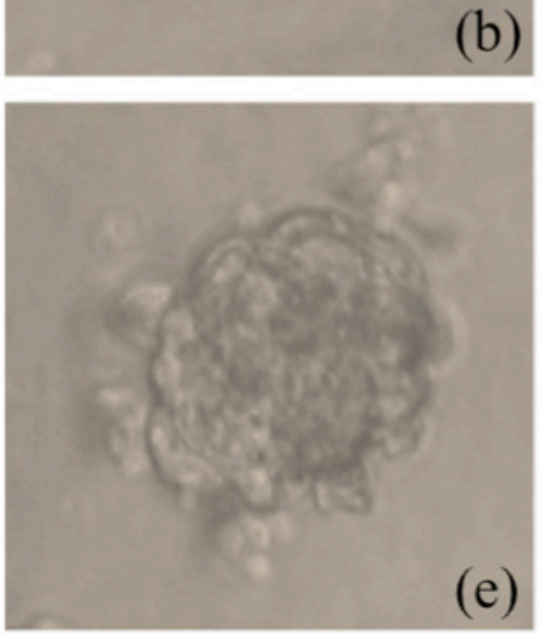

$24 \mathrm{~h}$
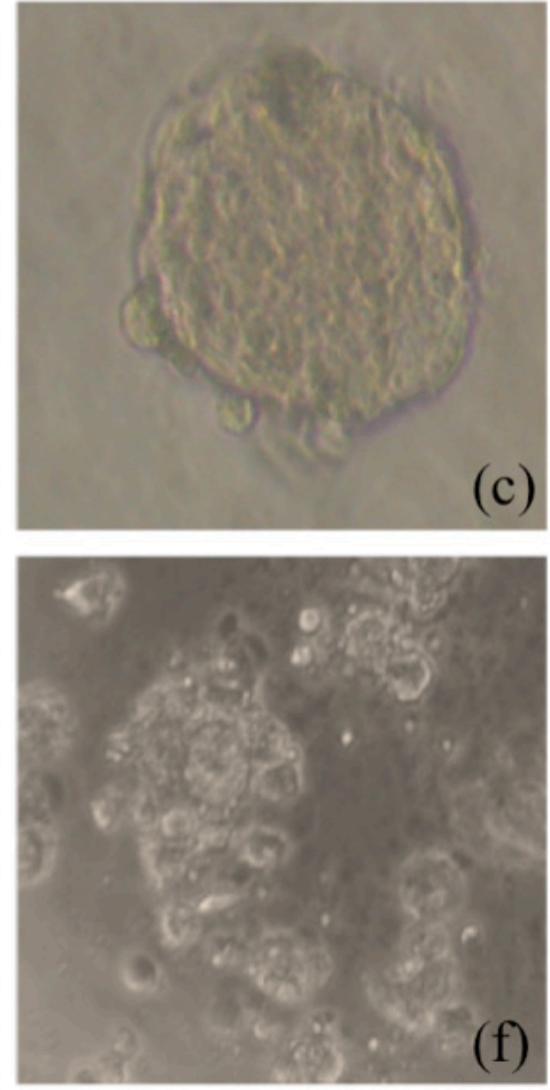

$48 \mathrm{~h}$

Figure 6. Spheroid formation assay. Representative images showing Spheroids' growth obtained from HUVEC PrPKD and scrambled siRNAs cells at 16, 24 and 48 h. Images were taken with a 20X objective.

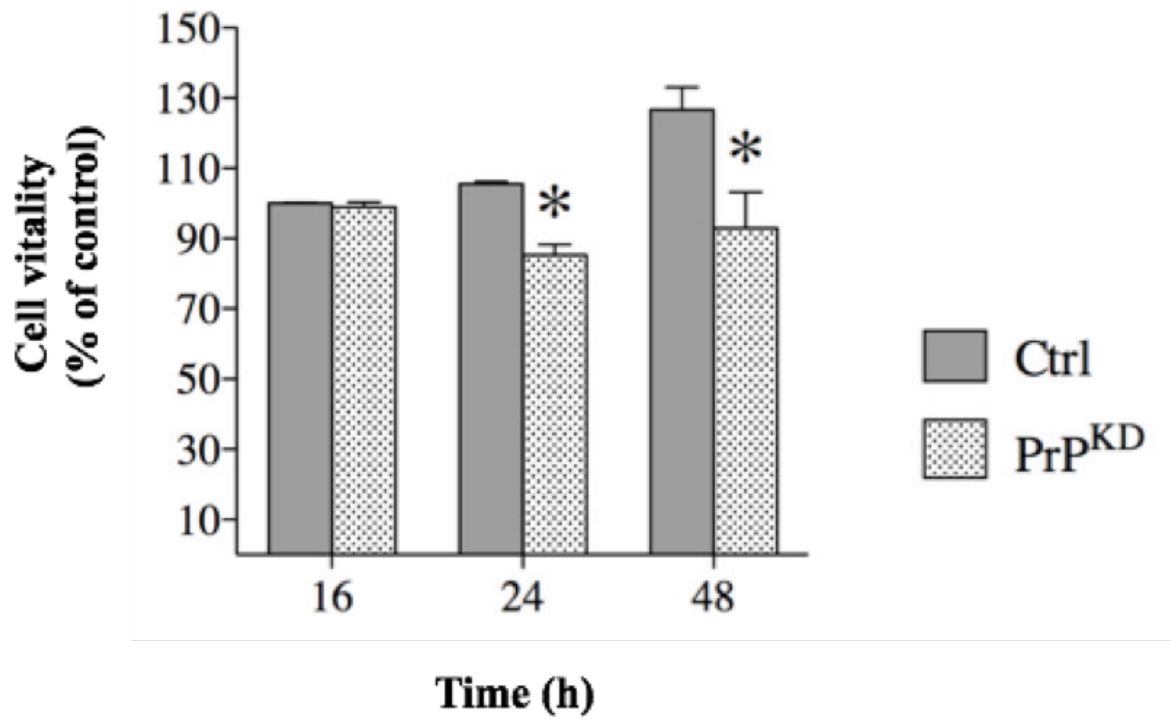

Figure 7. Spheroid-derived cell vitality assay. Cells derived from control (Ctrl) and knockdown (PrPKD) spheroids mechanically detached and counted at the given timepoints have been dyed with Trypan Blue 0,2\% in order to discriminate viable cells. The graph shows vitality percentage relative to the number of cultured cells counted in Ctrl spheroids after $16 h$. $\left(n=3 ;{ }^{*} p<0.05\right)$. 

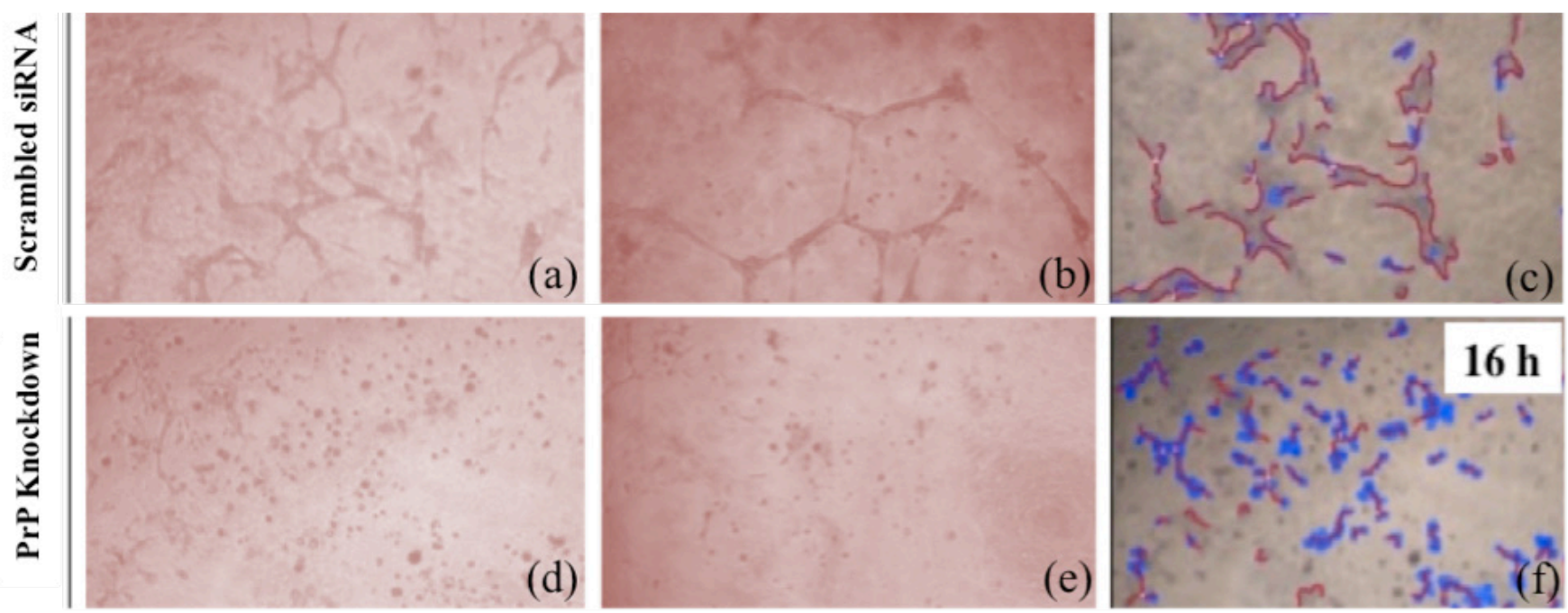

(g)
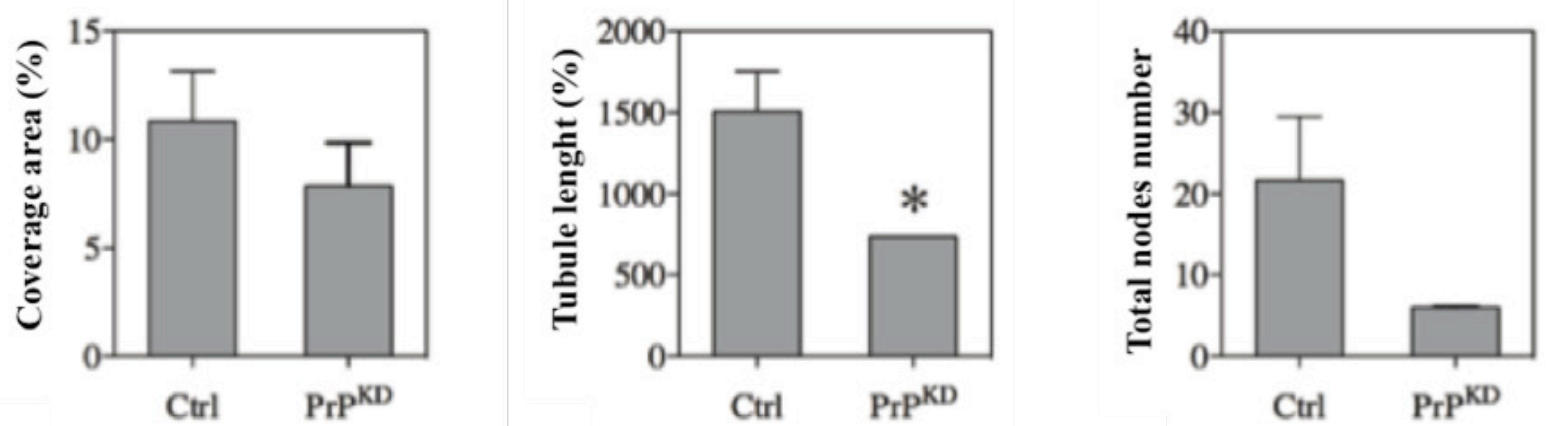

Figure 8. VEGF-induced tubulogenesis assay in Matrigel. HUVEC control (a-b) and PrPKD (d-e) seeded on Matrigel and stimulated for $16 \mathrm{~h}$. Images (c) and (f), relative to network analysis are performed by WimTube software (Wimasis GmbH, Germany). Histograms (g) are respectively referred to coverage area, tubules and knots; data reported are related to statistical analysis of images acquired in three independent experiments $\left({ }^{*} p<0.05\right)$.

a complex network: only a few and brief cellular extroflections (sprouts) are noted, indicating a reduced invasive capacity. On the other hand, cells transfected with scrambled siRNAs are able to form mature networks, with a fair number of nodes and branches, as illustrated by using the WimTube image analysis software (Wimasis Gmbh, Munich, Germany). This data clearly suggests $\mathrm{PrP}$ ability to interact with several extracellular matrix elements (data being confirmed). Since PrP regulates many different signal transduction pathways with effects on the cellular transcriptional activity, we evaluated Flt-1 and KDR receptors expression levels that may be involved in the cell response mechanism to VEGF growth factor. RT-PCR analysis highlights no significative differences between the receptor transcript levels in Ctrl and PrPKD cells as reported in Figure 9, strengthening the hypothesis of PrP VEGF-independent role in the endothelial cells morphogenesis mechanisms.
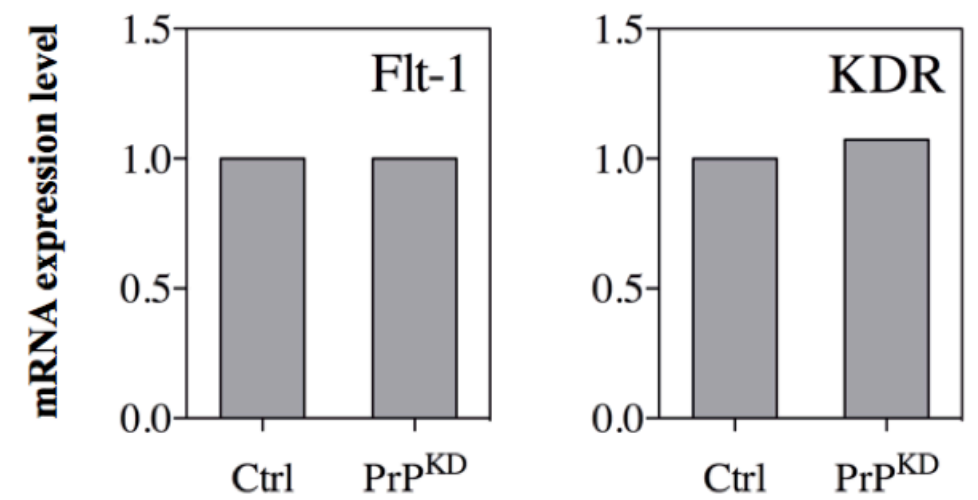

Figure 9. Flt-1 and KDR receptors transcript levels in Ctrl and PrPKD cells. Graphs show Flt-1 and KDR receptors transcript levels in HUVEC Ctrl and PrPKD cells. RT-PCR results have been normalized on GADPH transcript levels $(n=3)$. 


\section{Discussions and Conclusion}

Copper is an essential micronutrient, necessary for the proper growth, development and maintenance of connective tissue, bone, brain and heart and it has been shown to promote endothelial cell proliferation, mobilization and morphogenesis $(48,49)$. It has been reported that copper can induce angiogenesis by activating various compounds, which include angiogenin $(50)$ and tumour necrosis factor alpha (TNF $\alpha)(51,52)$. Furthermore, the silencing of CTR1 (copper transporter 1) using siRNA in copper-exposed HUVEC cell lines, inhibited the angiogenesis and reduced the vascular endothelial growth factor (VEGF) expression (53).

The prion protein seems to play a fundamental role in the etiology of various neurodegenerative disorders. At this regard, PrP protein abundantly expressed in the central nervous system and at lower levels in non-neuronal cells (including immune system cells), is known for its role in prion pathologies, such as Creutzfeldt-Jacobs disease occurring both in humans and animals (54-56). The $\mathrm{N}$-terminal octapeptide domains of the PrP protein can bind up to four copper ions (one for each octa-repeat region). In particular, the amino-terminal domain and the so-called "fifth site", consisting of histidine residues 96 and 111, each binding a copper ion, represent the candidate sites able to bind the substrate $\left(\mathrm{Cu}^{2+}\right)(18,22)$.

Endothelial cells express and present $\operatorname{PrP}$ on their surface (35). PrP has been reported to be a component of caveolae that take part to the signal transduction involved in cell survival, differentiation and angiogenesis (59). Satoh et al. have also seen that the disruption of the PrP gene results in an abnormal regulation of cell proliferation, differentiation and survival processes, including Ras and Rac pathways taking part to angiogenesis (60). In addition, PrP transcripts are expressed in the endothelial cells during the development of the neonatal brain, indicating a role in the angiogenesis of the central nervous system (CNS) and in the blood-brain barrier maturation $(60,61)$. Neurovascular dysfunctions have been identified as the primary cause of cognitive deterioration in neuro-degenerative diseases (39); it is also known that a reduced copper availability in nervous system may lead to the development of lesions at the CNS level $(24,62,63)$. On the other hand, dysomehostasis of copper ions and ceruloplasmin was found in Multiple Sclerosis patients (64). It is interesting to point out how recent experimental evidences identified the brain endothelium as a tissue able to preserve any variations in the systemic copper level or, at least, to be able to act as a sensor of copper bioavailability (38). Few neurophysiology and neuroimaging studies have also placed a link between trace elements involved in reduction-oxygenation cell processes and/or oxidative cell stress modulation and neurodevelopmental disorders such as Tourette syndrome (65-67).

Reduced copper availability has also been proposed as a reason for occlusion of cerebral arterial vessels in Alzheimer's Disease $(\mathrm{AD})$ patients that can evolve in thrombotic manifestations $(68,69)$.

Several lines of evidence suggest the PrP involvement in both physiological and pathological endothelial functions during the gestation period: in particular, $\operatorname{PrP}$ is expressed during early embryogenesis and could be a good candidate as a predictory marker in preeclampsia (28). About it, PrP overexpression in preeclamptic placenta may represent a compensatory response in order to overcome the preeclamptic condition (27).

In this work we demonstrated PrP expression in HUVEC endothelial cell lines and tried to establish: i. whether PrP can contribute to the endothelial function maintenance through copper availability modulation, and/or ii. to prove its involvement in cellular architecture and in adhesive cellular properties; both aspects were investigated in the HUVEC endothelial model, in which the expression of PrP was silenced by an RNA interference approach. The knockdown cells did not show any significant change in the proliferation rate under standard culture conditions (Fig. 1), as observed in other cell models (70), thus excluding a physiological role of $\mathrm{PrP}$ in cell cycle regulation. In addition, a reduced $\operatorname{PrP}$ expression did not alter the endothelial cells vitality, but, interestingly, this protein seems to act as a copper sensor, thanks to its ability to bind copper ions (Fig. 3).

The expression of $\operatorname{PrP}$ is strictly related to the copper availability as also shown from previous studies (20). Despite PrP ability to bind copper, the functional significance of this interaction is still unclear. In our work, HUVEC PrP-knockdown cells exhibited a reduced copper uptake (Fig. 5) and the use of different endocytosis inhibitors allowed us to demonstrate that endocytosis-dependent copper transport is predominantly mediated by the prion protein. We also showed, that PrP is able to translocate copper across membrane, firstly facilitating the metal reduction (Fig. 4), a necessary step needed for its internalization.

In order to study a possible role of $\operatorname{PrP}$ in the morphogenetic mechanisms, we set up spheroids formation and tubulogenic assays. The spheroids formation depends on the cellular ability to replicate even in absence of an anchoring surface, and their three-dimensionality critically depends on the cell capacity to create cell-to-cell adhesions and to synthetize extracellular matrix. In our work the reduced expression of PrP protein results in spheroids showing irregular morphology, which underwent a disaggregation process (Fig. 6-7). As spheroids may also represent an in vitro index of cell self-renewal, this result suggests how the prion protein plays a fundamental role in the regulation of stemness, proliferation and differentiation (71) and also that $\mathrm{PrP}$ is involved in vascular morphogenesis as an adhesion protein, mediating the interaction between endothelial cells and supporting cell growth under stress conditions $(72,73)$. The presence of blebs at the margins of the aggregates can suggest an apoptotic induction, as confirmed by the observed reduction of the proliferation rate (Fig. 7): this result could also be explained by the well-known protection role of PrP protein against oxidative stress $(13,15)$. Previous studies performed in spheroids derived from prostatitis tumor cells showed that mitochondrial generated ROS induce an increase of PrP protein expression and its cellular colocalization with mitochondrial 
enzymes such as superoxide dismutase (SOD1) and catalase (75). PrP is also responsible for the copper incorporation in cytosolic space where it is used as a cofactor for the $\mathrm{Cu}-\mathrm{Zn}-\mathrm{SOD}$ (15), acting directly as the SOD enzyme under stress conditions (heat shock, hypoxia, ischemia) (76). A down regulation of PrP was observed in a model of amyotrophic lateral sclerosis (ALS) (77); on the other hand $\operatorname{PrP}$ is able to reduce the amount of $\mathrm{A} \beta$ amyloid formation, suggesting that PrP expression should protect against the development of Alzheimer's Disease (78).

$\operatorname{PrP}$ has adhesion and transport functions because of the chance to establish homophilic interactions (PrP-PrP) (72) with other adhesion proteins $(13,73)$, and to influence their localization at the plasma membrane level (e.g. E-cadherin) (72). Current knowledge of $\operatorname{PrP}$ function in vascular remodeling is incomplete, and other studies seem to neglect the involvement of this protein in the angiogenic regulation of copper homeostasis, pointing out its significance in cell-to-cell and cell-toECM (extracellular matrix) interactions. The tubulogenesis assay of HUVEC PrP-knockdown cells in presence of VEGF165 and matrigel, showed a reduction of their sprouting capacity (Fig. 8). Therefore, we can assume a role of PrP in the maintenance of the physiological cell migration and adhesion properties. These processes are strongly related to the integrin family members expression (79) as for example integrin 1 which modulation is strictly dependent on $\operatorname{PrP}$ (80). $\operatorname{PrP}$ can interact with laminin receptor (LR), that has a pivotal role in cell adhesion and invasivity $(8,82)$, and it can also interact with $\mathrm{L} 1$, an adhesion molecule belonging to the immunoglobulin superfamily (83).

Altogether we demonstrate the functional expression of $\operatorname{PrP}$ in HUVEC cells and its role in copper reduction and cellular uptake. $\mathrm{PrP}$ is also involved in angiogenic processes as proved by its function in morphognesis of endothelial cells and in their ability to tubulogenesis. By virtue of all these properties, $\operatorname{PrP}$ can provide a link with the pathogenetic mechanism involved in vascular homeostasis.

\section{Conflict of interest statement}

The authors declare that they have no conflict of interest.

\section{References}

1. Wulf M-A, Senatore A, Aguzzi A. The biological function of the cellular prion protein: an update. BMC Biol [Internet]. BioMed Central; 2017 [cited 2019 Feb 13];15(1):34. Available from: http:// www.ncbi.nlm.nih.gov/pubmed/28464931

2. Panegyres $P$, Burchell JT. Prion diseases: immunotargets and therapy. ImmunoTargets Ther [Internet]. 2016 Jun [cited 2019 Apr 8];5:57. Available from: http://www.ncbi.nlm.nih.gov/pubmed/27529062

3. Walter E, Spevacek A, Visconte M, Rossi A, Millhauser G, Stevens D. Copper Binding Extrinsic to the Octarepeat Region in the Prion Protein. Curr Protein Pept Sci [Internet]. 2009 Oct [cited 2019 Feb 18];10(5):529-35. Available from: http://www.ncbi.nlm.nih.gov/ pubmed/19538144

4. Schmitt-Ulms G, Ehsani S, Watts JC, Westaway D, Wille H. Evolutionary descent of prion genes from the ZIP family of metal lon transporters. Poon AFY, editor. PLoS One [Internet]. 2009 Sep 28 [cited 2019 Feb 18];4(9):e7208. Available from: https://dx.plos. org/10.1371/journal.pone.0007208

5. Naslavsky N, Stein R, Yanai A, Friedlander G, Taraboulos A. Characterization of detergent-insoluble complexes containing the cellular prion protein and its scrapie isoform. J Biol Chem [Internet]. 1997 Mar 7 [cited 2019 Mar 11];272(10):6324-31. Available from: http://www.ncbi.nlm.nih.gov/pubmed/9045652

6. Zahn R, Liu A, Lührs T, Riek R, von Schroetter C, López García $F$, et al. NMR solution structure of the human prion protein. Proc Natl Acad Sci U S A [Internet]. 2000 Jan 4 [cited 2019 Mar 11];97(1):145-50. Available from: http://www.ncbi.nlm.nih.gov/ pubmed/10618385

7. Lawson VA, Collins SJ, Masters CL, Hill AF. Prion protein glycosylation [Internet]. Vol. 93, Journal of Neurochemistry. 2005 [cited 2019 Mar 11]. p. 793-801. Available from: http://www.ncbi.nlm. nih.gov/pubmed/15857383

8. Sarnataro D, Pepe A, Altamura G, De Simone I, Pesapane A, Nitsch $\mathrm{L}$, et al. The 37/67 kDa laminin receptor (LR) inhibitor, NSC47924, affects $37 / 67 \mathrm{kDa}$ LR cell surface localization and interaction with the cellular prion protein. Sci Rep [Internet]. 2016 Apr 13 [cited 2019 Mar 22];6(1):24457. Available from: http://www.nature.com/ articles/srep24457

9. Haigh CL, Edwards K, Brown DR. Copper binding is the governing determinant of prion protein turnover. Mol Cell Neurosci [Internet]. 2005 Oct [cited 2019 Mar 22];30(2):186-96. Available from: https://linkinghub.elsevier.com/retrieve/pii/S1044743105001478

10. Taylor DR. Assigning functions to distinct regions of the N-terminus of the prion protein that are involved in its copper-stimulated, clathrin-dependent endocytosis. J Cell Sci [Internet]. 2005 Nov 1 [cited 2019 Mar 11];118(21):5141-53. Available from: http://www. ncbi.nlm.nih.gov/pubmed/16254249

11. Ren K, Wang S-B, Chen C, Dong X-P, Sun H, Gao C, et al. PrP octarepeats region determined the interaction with caveolin-1 and phosphorylation of caveolin-1 and Fyn. Med Microbiol Immunol [Internet]. 2013 Jun 3 [cited 2019 Mar 11];202(3):215-27. Available from: http://link.springer.com/10.1007/s00430-012-0284-8

12. Cheng F, Lindqvist J, Haigh CL, Brown DR, Mani K. Copper-dependent co-internalization of the prion protein and glypican-1. J Neurochem [Internet]. 2006 Sep [cited 2019 Mar 11];98(5):1445-57. Available from: http://www.ncbi.nlm.nih.gov/pubmed/16923158

13. Castle AR, Gill AC. Physiological Functions of the Cellular Prion Protein. Front Mol Biosci [Internet]. 2017;4(April):1-25. Available from: http://journal.frontiersin.org/article/10.3389/fmolb.2017.00019/ full

14. D’Ambrosi N, Rossi L. Copper at synapse: Release, binding and modulation of neurotransmission. Neurochem Int [Internet]. 2015 Nov [cited 2019 Feb 14];90:36-45. Available from: http://www. ncbi.nlm.nih.gov/pubmed/26187063

15. Urso E, Manno D, Serra A, Buccolieri A, Rizzello A, Danieli A, et al. Role of the cellular prion protein in the neuron adaptation strategy to copper deficiency. Cell Mol Neurobiol [Internet]. 2012 Aug 24 [cited 2019 Mar 11];32(6):989-1001. Available from: http://link. springer.com/10.1007/s10571-012-9815-5

16. Hornshaw MP, McDermott JR, Candy JM, Lakey JH. Copper binding to the $\mathrm{N}$-terminal tandem repeat region of mammalian and avian prion protein: structural studies using synthetic peptides. Biochem Biophys Res Commun [Internet]. 1995 Sep 25 [cited 2019 Mar 22];214(3):993-9. Available from: http://linkinghub.elsevier.com/retrieve/pii/S0006291X85723844

17. Hornshaw MP, McDermott JR, Candy JM. Copper binding to the $\mathrm{N}$-terminal tandem repeat regions of mammalian and avian prion protein. Biochem Biophys Res Commun [Internet]. 1995 Feb 15 [cited 2019 Mar 22];207(2):621-9. Available from: http://www. ncbi.nlm.nih.gov/pubmed/7864852

18. Burns CS, Aronoff-Spencer E, Legname G, Prusiner SB, Antholine 
WE, Gerfen GJ, et al. Copper coordination in the full-length, recombinant prion protein. Biochemistry [Internet]. 2003 Jun 10 [cited 2019 Mar 22];42(22):6794-803. Available from: http://www. ncbi.nlm.nih.gov/pubmed/12779334

19. Jones S, Batchelor M, Bhelt D, Clarke AR, Collinge J, Jackson GS. Recombinant prion protein does not possess SOD-1 activity. Biochem J [Internet]. Portland Press Ltd; 2005 Dec 1 [cited 2019 Mar 25];392(Pt 2):309-12. Available from: http://www.ncbi.nlm.nih. gov/pubmed/16156720

20. Brown DR, Qin K, Herms JW, Madlung A, Manson J, Strome R, et al. The cellular prion protein binds copper in vivo. Nature [Internet]. Nature Publishing Group; 1997 Dec 18 [cited 2019 Feb 14];390(6661):684-7. Available from: http://www.nature.com/articles/37783

21. Brown LR, Harris DA. Copper and zinc cause delivery of the prion protein from the plasma membrane to a subset of early endosomes and the Golgi. J Neurochem [Internet]. 2003 Oct [cited 2019 Mar 25];87(2):353-63. Available from: http://www.ncbi.nlm. nih.gov/pubmed/14511113

22. Sánchez-López C, Rossetti G, Quintanar L, Carloni P. Structural Determinants of the Prion Protein N-Terminus and Its Adducts with Copper lons. Int J Mol Sci [Internet]. 2018 Dec 20 [cited 2019 Mar 22];20(1):18. Available from: http://www.mdpi.com/14220067/20/1/18

23. Giese A, Buchholz M, Herms J, Kretzschmar HA. Mouse brain synaptosomes accumulate copper-67 efficiently by two distinct processes independent of cellular prion protein. J Mol Neurosci [Internet]. 2005 [cited 2019 Mar 22];27(3):347-54. Available from: http://www.ncbi.nlm.nih.gov/pubmed/16280605

24. Zatta P, Frank A. Copper deficiency and neurological disorders in man and animals [Internet]. Vol. 54, Brain Research Reviews. 2007 [cited 2019 Mar 22]. p. 19-33. Available from: https://linkinghub. elsevier.com/retrieve/pii/S0165017306001147

25. Schlief ML, Gitlin JD. Copper Homeostasis in the CNS: A Novel Link Between the NMDA Receptor and Copper Homeostasis in the Hippocampus. Mol Neurobiol [Internet]. 2006 Apr [cited 2019 Mar 22];33(2):81-90. Available from: http://www.ncbi.nlm.nih.gov/pubmed/16603790

26. Leah Harris Z, Gitlin JD. Genetic and molecular basis for copper toxicity [Internet]. Vol. 63, American Journal of Clinical Nutrition. 1996 [cited 2019 Mar 20]. p. 836-77. Available from: https://academic.oup.com/ajcn/article-abstract/63/5/836S/4651493

27. Hwang HS, Park SH, Park YW, Kwon HS, Sohn IS. Expression of cellular prion protein in the placentas of women with normal and preeclamptic pregnancies. Acta Obstet Gynecol Scand [Internet]. John Wiley \& Sons, Ltd (10.1111); 2010 Sep 1 [cited 2019 Mar 25];89(9):1155-61. Available from: http://doi.wiley.com/10.3109/ 00016349.2010 .498497

28. Caniggia I, Winter J, Lye SJ, Post M. Oxygen and placental development during the first trimester: Implications for the pathophysiology of pre-eclampsia. Placenta [Internet]. W.B. Saunders; 2000 Mar 1 [cited 2019 Mar 21];21(SUPPL.1):S25-30. Available from: https://www.sciencedirect.com/science/article/pii/ S0143400499905222?via\%3Dihub

29. Donadio S, Alfaidy N, De Keukeleire B, Micoud J, Feige JJ, Challis JRG, et al. Expression and localization of cellular prion and COMMD1 proteins in human placenta throughout pregnancy. Placenta [Internet]. 2007 Aug [cited 2019 Mar 22];28(8-9):90711. Available from: https://linkinghub.elsevier.com/retrieve/pii/ S0143400406002761

30. Jeong JK, Seo JS, Moon MH, Lee YJ, Seol JW, Park SY. Hypoxia-inducible factor-1 alpha regulates prion protein expression to protect against neuron cell damage. Neurobiol Aging [Internet]. Elsevier; 2012 May 1 [cited 2019 Mar 21];33(5):1006.e1-1006.e10. Available from: https://www.sciencedirect.com/science/article/

\section{pii/S0197458011003915?via\%3Dihub}

31. Liang J, Bai F, Luo G, Wang J, Liu J, Ge F, et al. Hypoxia induced overexpression of $\operatorname{PrP}(\mathrm{C})$ in gastric cancer cell lines. Cancer Biol Ther [Internet]. 2007 May [cited 2019 Mar 22];6(5):769-74. Available from: http://www.ncbi.nlm.nih.gov/pubmed/17387271

32. Seo J-S, Seol J-W, Moon M-H, Jeong J-K, Lee Y-J, Park S-Y. Hypoxia protects neuronal cells from human prion protein fragment-induced apoptosis. J Neurochem [Internet]. John Wiley \& Sons, Ltd (10.1111); 2010 Feb 1 [cited 2019 Mar 21];112(3):715-22. Available from: http://doi.wiley.com/10.1111/j.1471-4159.2009.06496.x

33. Jeong JK, Park SY. Transcriptional regulation of specific protein 1 (SP1) by hypoxia-inducible factor 1 alpha (HIF-1a) leads to PRNP expression and neuroprotection from toxic prion peptide. Biochem Biophys Res Commun [Internet]. 2012 Dec 7 [cited 2019 Mar 22];429(1-2):93-8. Available from: http://www.ncbi.nlm.nih. gov/pubmed/23131565

34. Simák J, Holada K, D’Agnillo F, Janota J, Vostal JG. Cellular prion protein is expressed on endothelial cells and is released during apoptosis on membrane microparticles found in human plasma. Transfusion [Internet]. John Wiley \& Sons, Ltd (10.1111); 2002 Mar 1 [cited 2019 Mar 21];42(3):334-42. Available from: http://doi. wiley.com/10.1046/j.1537-2995.2002.00072.x

35. Starke R, Drummond O, MacGregor I, Biggerstaff J, Gale R, Camilleri $\mathrm{R}$, et al. The expression of prion protein by endothelial cells: a source of the plasma form of prion protein? Br J Haematol [Internet]. John Wiley \& Sons, Ltd (10.1111); 2002 Dec 1 [cited 2019 Mar 21];119(3):863-73. Available from: http://doi.wiley.com/10.1046/ j.1365-2141.2002.03847.x

36. Couraud P-O, Perriere N, Chaverot N, Enslen H, Cazaubon S, Viegas P. Junctional expression of the prion protein PrPC by brain endothelial cells: a role in trans-endothelial migration of human monocytes. J Cell Sci [Internet]. 2006 Nov 15 [cited 2019 Mar 22];119(22):4634-43. Available from: http://jcs.biologists.org/cgi/ doi/10.1242/jcs.03222

37. Schulze T, Follet J, Bailly $Y$, Lemaire-Vieille C, Cesbron J-Y, Heinen $E$, et al. Epithelial and endothelial expression of the green fluorescent protein reporter gene under the control of bovine prion protein $(\operatorname{PrP})$ gene regulatory sequences in transgenic mice. Proc Natl Acad Sci [Internet]. 2002 May 9 [cited 2019 Mar 22];97(10):5422-7. Available from: http://www.pnas.org/cgi/ doi/10.1073/pnas.080081197

38. Singh SK, Sinha P, Mishra L, Srikrishna S. Neuroprotective Role of a Novel Copper Chelator against A $\beta 42$ Induced Neurotoxicity. Int J Alzheimers Dis [Internet]. 2013 [cited 2019 Mar 22];2013:1-9. Available from: http://www.ncbi.nlm.nih.gov/pubmed/24159420

39. Urso E, Maffia M. Behind the Link between Copper and Angiogenesis: Established Mechanisms and an Overview on the Role of Vascular Copper Transport Systems [Internet]. Vol. 52, Journal of Vascular Research. 2015 [cited 2019 Feb 18]. p. 172-96. Available from: https://www.karger.com/Article/FullText/438485

40. Zlokovic B V. The Blood-Brain Barrier in Health and Chronic Neurodegenerative Disorders. Neuron [Internet]. 2008 Jan 24 [cited 2019 Mar 21];57(2):178-201. Available from: http://www.ncbi. nlm.nih.gov/pubmed/18215617

41. Guo S, Lo EH. Dysfunctional Cell-Cell Signaling in the Neurovascular Unit as a Paradigm for Central Nervous System Disease. Stroke [Internet]. 2009 Mar 1 [cited 2019 Mar 21];40(3, Supplement 1):S4-7. Available from: http://www.ncbi.nlm.nih.gov/pubmed/19064781

42. Nelson SK, Huang CJ, Mathias MM, Allen KGD. Copper-marginal and copper-deficient diets decrease aortic prostacyclin production and copper-dependent superoxide dismutase activity, and increase aortic lipid peroxidation in rats. J Nutr [Internet]. 1992 Nov 1 [cited 2019 Mar 22];122(11):2101-8. Available from: http:// www.ncbi.nlm.nih.gov/pubmed/1432251 
43. Tanaka KI, Kawahara M. Copper enhances zinc-induced neurotoxicity and the endoplasmic reticulum stress response in a neuronal model of vascular dementia. Front Neurosci [Internet]. Frontiers; 2017 Feb 9 [cited 2019 Mar 20];11(FEB):58. Available from: http:// journal.frontiersin.org/article/10.3389/fnins.2017.00058/full

44. Mosmann T. Rapid colorimetric assay for cellular growth and survival: application to proliferation and cytotoxicity assays. J Immunol Methods [Internet]. 1983 Dec 16 [cited 2019 Mar 22];65(1-2):55-63. Available from: http://www.ncbi.nlm.nih.gov/ pubmed/6606682

45. Pfaff MW. A new mathematical model for relative quantification in real-time RT-PCR. Nucleic Acids Res [Internet]. 2001 May 1 [cited 2019 Mar 22];29(9):e45. Available from: http://www.ncbi.nlm.nih. gov/pubmed/11328886

46. Foty R. A Simple Hanging Drop Cell Culture Protocol for Generation of 3D Spheroids. J Vis Exp [Internet]. 2011 May 6 [cited 2019 Mar 22];(51). Available from: http://www.ncbi.nlm.nih.gov/pubmed/21587162

47. Mehta G, Hsiao AY, Ingram M, Luker GD, Takayama S. Opportunities and challenges for use of tumor spheroids as models to test drug delivery and efficacy. J Control Release [Internet]. 2012 Dec 10 [cited 2019 Apr 8];164(2):192-204. Available from: http://www. ncbi.nlm.nih.gov/pubmed/22613880

48. Landriscina M, Bagalá C, Mandinova A, Soldi R, Micucci I, Bellum $\mathrm{S}$, et al. Copper induces the assembly of a multiprotein aggregate implicated in the release of fibroblast growth factor 1 in response to stress. J Biol Chem [Internet]. 2001 Jul 6 [cited 2019 Mar 22];276(27):25549-57. Available from: http://www.jbc.org/ lookup/doi/10.1074/jbc.M102925200

49. Yee EMH, Brandl MB, Pasquier E, Cirillo G, Kimpton K, Kavallaris M, et al. Dextran-Catechin inhibits angiogenesis by disrupting copper homeostasis in endothelial cells. Sci Rep [Internet]. 2017 Dec 9 [cited 2019 Mar 22];7(1):7638. Available from: http://www.ncbi. nlm.nih.gov/pubmed/28794411

50. Soncin F, Guitton JD, Cartwright T, Badet J. Interaction of human angiogenin with copper modulates angiogenin binding to endothelial cells. Biochem Biophys Res Commun [Internet]. 1997 Jul 30 [cited 2019 Mar 25];236(3):604-10. Available from: http:// linkinghub.elsevier.com/retrieve/pii/S0006291X97970182

51. Pan Q, Kleer CG, van Golen KL, Irani J, Bottema KM, Bias C, et al. Copper deficiency induced by tetrathiomolybdate suppresses tumor growth and angiogenesis. Cancer Res [Internet]. 2002 Sep 1 [cited 2019 Mar 25];62(17):4854-9. Available from: http://www. ncbi.nlm.nih.gov/pubmed/12208730

52. Harris DA. Trafficking, turnover and membrane topology of $\mathrm{PrP} . \mathrm{Br}$ Med Bull [Internet]. 2003 [cited 2019 Mar 22];66:71-85. Available from: http://www.ncbi.nlm.nih.gov/pubmed/14522850

53. Narayanan G, R BS, Vuyyuru H, Muthuvel B, Konerirajapuram Natrajan S. CTR1 silencing inhibits angiogenesis by limiting copper entry into endothelial cells. Arai K, editor. PLoS One [Internet]. 2013 Sep 9 [cited 2019 Mar 25];8(9):e71982. Available from: https://dx.plos.org/10.1371/journal.pone.0071982

54. Mays CE, Coomaraswamy J, Watts JC, Yang J, Ko KWS, Strome B, et al. Endoproteolytic processing of the mammalian prion glycoprotein family. FEBS J [Internet]. 2014 Feb [cited 2019 Mar 22];281(3):862-76. Available from: http://www.ncbi.nlm.nih.gov/ pubmed/24286250

55. Winklhofer KF, Tatzelt J, Haass C. The two faces of protein misfolding: gain- and loss-of-function in neurodegenerative diseases. EMBO J [Internet]. 2008 Jan 23 [cited 2019 Mar 22];27(2):336-49. Available from: http://www.ncbi.nlm.nih.gov/pubmed/18216876

56. Salvesen $\varnothing$, Tatzelt J, Tranulis MA. The prion protein in neuroimmune crosstalk. Neurochem Int [Internet]. 2018 Nov [cited 2019 Mar 22]; Available from: https://linkinghub.elsevier.com/retrieve/ pii/S0197018618303073
57. Cereghetti GM, Schweiger A, Glockshuber R, Van Doorslaer S. Electron Paramagnetic Resonance Evidence for Binding of Cu2+ to the C-terminal Domain of the Murine Prion Protein. Biophys J [Internet]. 2001 Jul [cited 2019 Mar 22];81(1):516-25. Available from: http://www.ncbi.nlm.nih.gov/pubmed/11423433

58. Whittal RM, Ball HL, Cohen FE, Burlingame AL, Prusiner SB, Baldwin MA. Copper binding to octarepeat peptides of the prion protein monitored by mass spectrometry. Protein Sci [Internet]. 2000 Feb [cited 2019 Mar 22];9(2):332-43. Available from: http://doi. wiley.com/10.1110/ps.9.2.332

59. Massimino ML, Griffoni C, Spisni E, Toni M, Tomasi V. Involvement of caveolae and caveolae-like domains in signalling, cell survival and angiogenesis. Cell Signal [Internet]. 2002 Feb [cited 2019 Mar 22];14(2):93-8. Available from: http://www.ncbi.nlm.nih.gov/pubmed/11781132

60. Satoh J, Kuroda Y, Katamine S. Gene expression profile in prion protein-deficient fibroblasts in culture. Am J Pathol [Internet]. 2000 Jul [cited 2019 Mar 22];157(1):59-68. Available from: http:// www.ncbi.nlm.nih.gov/pubmed/10880376

61. Li C, Yan Z, Yang J, Chen H, Li H, Jiang Y, et al. Neuroprotective effects of resveratrol on ischemic injury mediated by modulating the release of neurotransmitter and neuromodulator in rats. Neurochem Int [Internet]. 2010 Feb [cited 2017 Jul 19];56(3):495500. Available from: http://linkinghub.elsevier.com/retrieve/pii/ S0197018609003337

62. Rogers JT, Lahiri DK. Metal and inflammatory targets for Alzheimer's disease. Curr Drug Targets [Internet]. 2004 Aug [cited 2019 Mar 25];5(6):535-51. Available from: http://www.ncbi.nlm.nih. gov/pubmed/15270200

63. Rivera-Mancía S, Pérez-Neri I, Ríos C, Tristán-López L, Rivera-Espinosa $L$, Montes $S$. The transition metals copper and iron in neurodegenerative diseases. Chem Biol Interact [Internet]. 2010 Jul 30 [cited 2019 Mar 25];186(2):184-99. Available from: https://linkinghub.elsevier.com/retrieve/pii/S0009279710002711

64. De Riccardis L, Buccolieri A, Muci M, Pitotti E, De Robertis F, Trianni $G$, et al. Copper and ceruloplasmin dyshomeostasis in serum and cerebrospinal fluid of multiple sclerosis subjects. Biochim Biophys Acta - Mol Basis Dis [Internet]. 2018 May [cited 2019 Mar 11];1864(5):1828-38. Available from: https://linkinghub.elsevier. com/retrieve/pii/S0925443918300875

65. Robertson M, Evans K, Robinson A, Trimble M, Lascelles P. Abnormalities of copper in Gilles de la Tourette syndrome. Biol Psychiatry [Internet]. 1987 Aug [cited 2019 Mar 25];22(8):968-78. Available from: http://www.ncbi.nlm.nih.gov/pubmed/3475133

66. Gorman DA, Zhu H, Anderson GM, Davies M, Peterson BS. Ferritin Levels and Their Association With Regional Brain Volumes in Tourette's Syndrome. Am J Psychiatry [Internet]. 2006 Jul 1 [cited 2019 Mar 25];163(7):1264-72. Available from: http://www.ncbi. nlm.nih.gov/pubmed/16816233

67. Udvardi PT, Nespoli E, Rizzo F, Hengerer B, Ludolph AG. Nondopaminergic Neurotransmission in the Pathophysiology of Tourette Syndrome. In 2013 [cited 2018 Mar 5]. p. 95-130. Available from: http://linkinghub.elsevier.com/retrieve/pii/ B9780124115460000044

68. Hamilton IMJ, Gilmore WS, Strain JJ. Marginal Copper Deficiency and Atherosclerosis. Biol Trace Elem Res [Internet]. 2000 [cited 2019 Mar 22];78(1-3):179-90. Available from: http://www.ncbi. nlm.nih.gov/pubmed/11314977

69. Casserly IP, Topol EJ. Convergence of atherosclerosis and alzheimer's disease: Cholesterol, inflammation, and misfolded proteins. Discov Med [Internet]. 2004 Jun [cited 2019 Mar 22];4(22):149-56. Available from: http://www.ncbi.nlm.nih.gov/pubmed/20704977

70. Yu G, Jiang L, Xu Y, Guo H, Liu H, Zhang Y, et al. Silencing Prion Protein in MDA-MB-435 Breast Cancer Cells Leads to Pleiotropic Cellular Responses to Cytotoxic Stimuli. Lasmezas Cl, editor. PLoS 
One [Internet]. 2012 Nov 2 [cited 2019 Mar 22];7(11):e48146. Available from: http://dx.plos.org/10.1371/journal.pone.0048146

71. Corsaro A, Bajetto A, Thellung S, Begani G, Villa V, Nizzari M, et al. Cellular prion protein controls stem cell-like properties of human glioblastoma tumor-initiating cells. Oncotarget [Internet]. Impact Journals, LLC; 2016 Jun 21 [cited 2019 Mar 20];7(25):38638-57. Available from: http://www.ncbi.nlm.nih.gov/pubmed/27229535

72. Málaga-Trillo E, Solis GP, Schrock Y, Geiss C, Luncz L, Thomanetz V, et al. Regulation of embryonic cell adhesion by the prion protein. Weissmann C, editor. PLoS Biol [Internet]. 2009 Mar 10 [cited 2019 Mar 22];7(3):e55. Available from: https://dx.plos.org/10.1371/ journal.pbio. 1000055

73. Santuccione A, Sytnyk V, Leshchyns'ka I, Schachner M. Prion protein recruits its neuronal receptor NCAM to lipid rafts to activate p59fyn and to enhance neurite outgrowth. J Cell Biol [Internet]. 2005 Apr 25 [cited 2019 Mar 22];169(2):341-54. Available from: http://www.jcb.org/lookup/doi/10.1083/jcb.200409127

74. Zocche Soprana H, Canes Souza L, Debbas V, Martins Laurindo FR. Cellular prion protein (PrPC) and superoxide dismutase (SOD) in vascular cells under oxidative stress. Exp Toxicol Pathol [Internet]. 2011 Mar [cited 2019 Mar 22];63(3):229-36. Available from: https://linkinghub.elsevier.com/retrieve/pii/S0940299309002991

75. Sauer H, Dagdanova A, Hescheler J, Wartenberg M. Redox-regulation of intrinsic prion expression in multicellular prostate tumor spheroids. Free Radic Biol Med [Internet]. 1999 Dec [cited 2019 Mar 22];27(11-12):1276-83. Available from: http://www.ncbi.nlm. nih.gov/pubmed/10641721

76. Shyu W-C, Lin S-Z, Chiang M-F, Ding D-C, Li K-W, Chen S-F, et al. Overexpression of PrPC by adenovirus-mediated gene targeting reduces ischemic injury in a stroke rat model. J Neurosci [Internet]. 2005 Sep 28 [cited 2019 Mar 22];25(39):8967-77. Available from: http://www.jneurosci.org/cgi/doi/10.1523/JNEUROSCl.1115-05.2005

77. Dupuis L, Mbebi C, Gonzalez de Aguilar J-L, Rene F, Muller A, de Tapia M, et al. Loss of Prion Protein in a Transgenic Model of
Amyotrophic Lateral Sclerosis. Mol Cell Neurosci [Internet]. 2002 Feb [cited 2019 Mar 22];19(2):216-24. Available from: http://www. ncbi.nlm.nih.gov/pubmed/11860274

78. Whitehouse IJ, Miners JS, Glennon EBC, Kehoe PG, Love S, Kellett $K A B$, et al. Prion protein is decreased in Alzheimer's brain and inversely correlates with BACE1 activity, amyloid- $\beta$ levels and Braak stage. PLoS One [Internet]. Public Library of Science; 2013 [cited 2019 Mar 25];8(4):e59554. Available from: http://www.ncbi.nlm. nih.gov/pubmed/23577068

79. Hood JD, Cheresh DA. Role of integrins in cell invasion and migration. Nat Rev Cancer [Internet]. 2002 Feb [cited 2019 Mar 25];2(2):91-100. Available from: http://www.ncbi.nlm.nih.gov/ pubmed/12635172

80. Loubet D, Dakowski C, Pietri M, Pradines E, Bernard S, Callebert J, et al. Neuritogenesis: the prion protein controls $\beta 1$ integrin signaling activity. FASEB J [Internet]. 2012 Feb [cited 2019 Mar 22];26(2):678-90. Available from: http://www.fasebj.org/ doi/10.1096/fj.11-185579

81. Gauczynski S, Peyrin JM, Haïk S, Leucht C, Hundt C, Rieger R, et al. The $37-\mathrm{kDa} / 67-\mathrm{kDa}$ laminin receptor acts as the cell-surface receptor for the cellular prion protein. EMBO J [Internet]. 2001 Nov 1 [cited 2019 Mar 22];20(21):5863-75. Available from: http://emboj. embopress.org/cgi/doi/10.1093/emboj/20.21.5863

82. Mbazima V, Da Costa Dias B, Omar A, Jovanovic K, Weiss SFT. Interactions between $\operatorname{PrP}(\mathrm{c})$ and other ligands with the 37-kDa/67-kDa laminin receptor. Front Biosci (Landmark Ed [Internet]. 2010 Jun 1 [cited 2019 Mar 22];15:1150-63. Available from: http://www.ncbi. nlm.nih.gov/pubmed/20515747

83. Watts JC, Huo H, Bai Y, Ehsani S, Jeon AHW, Won AH, et al. Interactome analyses identify ties of PrP and its mammalian paralogs to oligomannosidic $\mathrm{N}$-glycans and endoplasmic reticulum-derived chaperones. Mabbott N, editor. PLoS Pathog [Internet]. 2009 Oct 2 [cited 2019 Mar 22];5(10):e1000608. Available from: https://dx.plos.org/10.1371/journal.ppat.1000608 